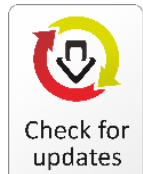

updates
Article Type: Research Paper

\section{Intellectual Capital and Firm Performance in ASEAN: The Role of Research and Development}

\author{
Bima Cinintya Pratama* ${ }^{1}$, Hardiyanto Wibowo ${ }^{1}$, Maulida Nurul Innayah ${ }^{2}$
}

\begin{abstract}
This paper aims to investigate the association between intellectual capital, research and development, and firm financial performance in an emerging market context, which is ASEAN. The effect of Intellectual Capital and Research and Development Intensity towards firm financial performance is examined while testing the moderating role of research and development on the relationship between intellectual capital and firm financial performance. Panel data regression model analysis is used for a sample of non-financial companies in ASEAN countries, namely Indonesia, Malaysia, Philippines, and Singapore during 2015-2017. The final sample used in this study consists of a total of 383 observations. The results showed that intellectual capital has a positive effect on firm financial performance. This result indicates that intellectual capital can generate higher financial performance for the firms. A similar result also found in the relationship between research and development intensity and firm financial performance. Meanwhile, research and development are proved to be able to moderate the positive relationship between intellectual capital and firm financial performance. This result means that if the companies could facilitate their intellectual capital by giving more intensity of research and development, intellectual capital will be generated even more performance for the firms. This result implies that firms should utilize and maintain intellectual capital together with research and development.
\end{abstract}

Pratama, B.C., Wibowo, H., \& Innayah, M.N. (2019). Intellectual Capital and Firm Performance in ASEAN: The Role of Research and Development. Journal of Accounting and Investment, 20(3), 236-250.

\section{ARTICLE HISTORY \\ Received:}

27 April 2019

Reviewed:

16 July 2019

Revised:

3 September 2019

Accepted:

3 September 2019
Keywords: Intellectual Capital; Research and Development; Firm Performance

\section{Introduction}

The $13^{\text {th }}$ ASEAN Summit in Singapore 2007 has produced the ASEAN Economic Community Blueprint. One of the issues that emerging from the event was the enactment of the ASEAN Economic Community (AEC). AEC has been enacted actively by the end of 2015. While, AEC can improve ASEAN to be more dynamic and competitive region, it also will make the competition between firms inside ASEAN region become increasingly competitive. This condition requires the firm to utilize its resources more effectively and efficiently so that the firm can create value-added and compete on the AEC. 
According to the resource-based theory, intellectual capital (hereinafter referred to as IC) is a resource that serves as the core of value creation and competitive advantage for the firm (Barney, 1991). Chen, Cheng, and Hwang (2005) and Wang (2008) explained that the sustainable competitive advantages from IC will make the firm won the competition with other firms and also create added value so that it will contribute to the firm's success. Previous studies have attempted to examine the relationship between the IC and the firm's performance, but the results are still not consistent. The studies from Firer and Stainbank (2003), Chen et al. (2005), Tan et al. (2007), Clarke, Seng, and Whiting (2011), Pratama (2016), and Pratama and Wibowo (2017) found that IC is positively related to the firm financial performance and market performance. Meanwhile, the studies from Firer and Williams (2003), Chan (2009), Maditinos, Chatzoudes, Tsairidis, and Theriou (2011), and Andriana (2014) could not find any evidence to support the relationship between IC and the firm performance. Due to the inconsistency in those results of previous studies and also because of limited number of studies that have been conducted on developing countries at the regional level, particularly in ASEAN, the first purpose of this study is to examine the positive effect of IC towards firm financial performance in ASEAN. It is also interesting to understand the role of intellectual capital on firm performance after the enactment of ASEAN Economic Community so that it can predict the importance of intellectual capital as one of the main resources in competing in the era of $A E C$.

Referring to the Resource-based theory, this study will try to explain the role of research and development as an effort to provide a competitive advantage for the firms. Research and Development are viewed as what is needed by almost every company to succeed in this competitive environment. As explained by Padgett and Galan (2010), through research and development (RnD) activities, firms can develop their products and have better production processes and effective sales innovations. Companies that allocate higher Research and Development expenditures are expected to get more benefits than those that do not (Wang, 2011). Referring to the research of Usman, Shaique, Khan, Shaikh, and Baig (2017) and Ghaffar (2014) who have examined the effect of RnD towards firm financial performance, the results of their studies stated that $\mathrm{RnD}$ had a positive effect towards the firm financial performance. Therefore, the second objective of this study is to examine the positive effect of research and development towards firm financial performance.

Furthermore, this study attempts to examine the moderating role of $\mathrm{RnD}$ to strengthen the relationship between IC and firm financial performance. RnD will affect intellectual capital resources in the process of corporate development and corporate value creation. It is because IC needs some innovation capabilities in order to generate maximum value for the company. Karchegani, Sofian, and Amin (2013) explained that intellectual capital (IC) is a vital asset that helps companies to create value and enables the companies to be innovative by boosting the organizational performance through knowledge, experiences, skills of employees and also by defining new methods of task performance and being innovative in their processes. On the other hand, to be able to affect the company's innovation, IC needs to be systematically supported by innovation capabilities, one of which could be expressed by companies RnD intensity. Therefore, 
this study expects that the existence of research and development will lead to more optimal impact from intellectual capital in improving the firm financial performance. Thus, the third objective of this study was to examine role of $\mathrm{RnD}$ intensity in strengthening the effect of IC towards firm financial performance.

This study uses a monetary measurement to measure the firm's IC, namely the valueadded intellectual coefficient (VAIC) developed by Pulic $(2000,2004)$. Panel data regression model analysis is used for a sample of non-financial companies in ASEAN countries, namely Indonesia, Malaysia, Philippines, and Singapore during 2015-2017. The countries are used because of the data availability limitation, as mostly, the companies from those countries also publish English versions of their annual reports. Non-financial companies are selected for this study because the industry often conducted research and development activity in their processes. This study contributes to the literature by testing the effect of IC and RnD towards financial performance. Furthermore, this study also contributes to the literature by testing the moderating role of $\mathrm{RnD}$ to see whether the RnD strengthens the effect of IC towards firm financial performance.

\section{Literature Review and Hypotheses Development}

\section{Resource-Based Theory}

RBT serves as an important framework to explain and predict what can be underlying for competitive advantage and firm performance of a company (Barney, Ketchen, \& Wright, 2011). RBT explained that the creation of sustainable competitive advantage is closely related to the firm ability to maintain valuable, rare, and irreplaceable resources also allocate and deploy these resources effectively (Barney, 1991). Companies will be able to win the competition and also create value-added so that it will contribute to the firm's success by utilizing sustainable competitive advantages from IC (Chen et al., 2005 and Wang, 2008).

Kozlenkova, Samaha, and Palmatier (2014) explained that the basic logic of this theory is based on two fundamental assumptions regarding the firm resources and explain how these resources can generate sustainable competitive advantage and why some firms can consistently outperform the others. First, the firm has a different set of resources, even within the same industry (Peteraf and Barney, 2003). Assumptions regarding the heterogeneity of these resources show that some firms have better expertise in completing certain activities because it has unique resources (Peteraf and Barney, 2003). Second, differences in resources will remain there due to difficulties in exchanging resources between firms (resource immobility assumption), which will lead to the advantage of the heterogeneity of these resources continue to occur from time to time (Kozlenkova et al., 2014).

Kozlenkova et al., (2014) explained Valuable, Rare, imperfectly imitable, Organization (VRIO) as characteristics that showed four conditions to assess how potential a resource 
will be able to generate sustainable competitive advantage. The following are VRIO characteristics:

a. Valuable; A firm resource is valuable if the resource enables firms to develop and implement strategies that can reduce corporate costs and/or increase the firm revenue more than when the resources are not present.

b. Rare; Resources could be said to be rare if those resources only controlled by a small number of competing firms. If these resources are valuable but not rare, the utilization of those resources will produce competitive equality, because the other firms that also having these resources also have the ability to utilize it.

c. Imperfectly imitable; Imperfectly imitable resources are resources that cannot be obtained through duplication or direct substitution by firms that do not have it.

d. Organization; The firm resources should be able to be organized so that the potential competitive of those resources can be utilized maximally. Organizations should act as adjustment factors that allow the firms to fully use the benefits contained in the resource.

Based on the explanation, according to RBT, IC has great potential to meet the VRIO characteristics so it can create a competitive advantage for the firm. By the competitive advantage of IC, firms can use it to compete in a competitive market and achieve optimal performance.

\section{Intellectual Capital}

Intellectual capital is a set of intangible assets or resources that are owned and utilized by companies to create corporate value and competitive advantage (Nahapiet and Ghoshal, 1998). Some researchers have different explanations regarding this IC, one of which is Bontis (1996) which explained that IC is something that is difficult to understand, but when it is discovered and exploited it can give companies new resources that can provide strength for companies to compete and win the competition. Meanwhile, Sullivan and Sullivan (2000) stated that IC is the knowledge that can be converted into profit, in which not only concerns about the knowledge and skills of employees but also includes the infrastructure of the company, relations with customers, information systems, technology and the ability to innovate and create. Based on these explanations, it can be concluded that IC plays an important role in value creation and the company's growth sustainability. Pulic $(2000,2004)$ suggests a model for measuring IC, namely VAIC (Value added intellectual coefficient). The VAIC method describes three main components of intellectual capital, namely Human capital, Structural Capital and Relational capital, and also Capital Employed.

VAIC model started by calculating a firm's ability to create value-added (VA). VA is the difference between the output (OUT) and the input (IN) and formulated in the following equation:

$$
\text { VA }=\text { OUT }- \text { IN }
$$


The output (OUT) represents revenue that covers all products and services sold by the firm. Input (IN) including all expenses incurred to generate revenue with the exception of employee costs. It is important to note that in this model, employee costs are not included in the IN. Due to its active role in the process of value creation, intellectual potential represented by employee costs are not counted as an expense. Thus, a key aspect of the VAIC method is by treating the employee as a value-creating entity. The calculation resulted in VA which reveals the wealth of the firm in the period. VA is influenced by both the efficiency of human capital (HC) and structural capital (SC).

The first relationship of VA is between VA and $\mathrm{HC}$ are known as Human Capital Efficiency (HCE). HCE shows the ability of HC to create value in the firm. Similarly, when HCE compared to some groups of firms, HCE serves as an indicator of the quality of human resources owned by the firm and their ability to generate VA for each unit of money spent on the HC. Pulic (2000) argues that the total cost of salaries and wages can be an indicator of $\mathrm{HC}$ because the market determines the salaries and wages as a result or impact of the firm performance, then it would be logical if the success of the HC declared with the same criteria. The relationship between VA and $\mathrm{HC}$ can be formulated as follows:

\section{HCE $=$ VA $/ H C$}

The second relationship is Structural Capital Efficiency (SCE), which shows the contribution of structural capital (SC) in the value creation. In the VAIC model, SC is calculated by subtracting VA with $\mathrm{HC}$. The smaller the contribution of $\mathrm{HC}$ in value creation, the greater the contribution of SC. In other words, the relationship between VA and SC is calculated in different ways because $\mathrm{HC}$ and $\mathrm{SC}$ are in inverse proportion in the firm value creation. SCE measures the amount of SC required for one unit of money of VA and serves as an indication of how SC success in value creation. Unlike HCE, VA is the denominator for SCE. Thus, the relationship between VA and SC is calculated by the following equation:

\section{SCE $=$ SC $/$ VA}

The third relationship of VA is with the physical capital (CE), known as the Capital Employed Efficiency (CEE). CEE is an indicator for VA created by a unit of physical capital. CEE can be formulated as follows:

\section{$\mathrm{CEE}=\mathrm{VA} / \mathrm{CE}$}

Pulic $(2000,2004)$ assumes that if the one-unit of CE generates greater profits in the firm than others, then the firm is better in utilizing its CE. Thus, better utilization of CE is also part of the firm's IC. When compared to a group of firms, CEE serve as an indicator of firm intellectual ability to utilize physical capital more optimally. 
The last step is calculating the firm overall intellectual ability. This calculation is the sum of the coefficients mentioned earlier. This resulted in a new and unique indicator, namely:

\section{VAIC $=H C E+S C E+C E E$}

Several studies and literature showed that VAIC is a promising measurement mechanism for measuring IC. Firer and Williams (2003) have mentioned the advantages of VAIC method, namely VAIC provide a consistent and standardized measurement basis that allow effective comparative analysis between firms and between countries; Data used in VAIC calculation is based on data that has been audited in the financial statements so that the calculation will be more objective. In addition, VAIC also has been used in several studies with the different industry settings that listed in the various countries stock exchanges, for example, the Johannesburg Stock Exchange, Taiwan Stock Exchange, Singapore Exchange, Hong Kong Stock Exchange, Athens Stock Exchange and the Australian Stock Exchange (Firer and Williams, 2003; Chen et al., 2005; Tan et al., 2007; Chan, 2009; Maditinos et al., 2011; Clarke et al., 2011). The literature also indicates that the VAIC has been used in the study of developing countries, like Taiwan, Greece, and South Africa to examine the relationship between IC and firm performance (Chen et al., 2005; Maditinos et al., 2011; Firer and Williams, 2003).

\section{Hypotheses Development}

Research and development is a research strategy or method that is powerful enough to improve practice (Sukmadinata, 2009). Kinkel, Lay, and Wengerl (2005) explained that an increase in research and development will lead to innovative and high-tech products, and enable companies to gain competitive advantage and gain market share. Therefore, more resources should be spent on Research and development activities to achieve the company's competitive advantage. The results of research and development are not only the development of an existing product but also to find knowledge or problems with practical answers. Research and development provide opportunities for companies to develop better products and production processes and more effective sales innovations to increase company value (Padgett and Galan, 2010).

The previous study from Gleason and Klock (2006) showed that research and development intensity has a positive effect on firm value. This supports the results of Oswald and Zarowin's study (2007) which showed that research and development activities are positively related and can explain business entities' value changes. In addition, Usman, et al. (2017) and Ghaffar (2014) who have examined the effect of research and development on corporate financial performance successfully proved that research and development have a positive effect on the company's financial performance.

IC plays an important role in value creation and the company's growth sustainability. This is in line with the Resource-Based Theory (RBT), which explains that IC is the core of value creation and the company's competitive advantage (Barney, 1991). From the RBT 
perspective, the creation of sustainable competitive advantage is closely related to the company's ability to maintain valuable, rare and irreplaceable resource assets and allocate and deploy these resources effectively (Barney, 1991). With the existence of sustainable competitive advantages, companies that have those advantages will be able to win the competition in the market so that they will eventually create value and achieve optimal performance. Previous studies showed that the role of Intellectual capital in improving firm performance. Studies from Chen et al. (2005), Clarke et al. (2011), Pratama (2016), Pratama and Wibowo (2017), and Pratama (2018) found that IC is positively related to the firm financial performance. Based on the explanations that have been described, the hypothesis that can be proposed is:

$\boldsymbol{H}_{1}$ : Intellectual capital has a positive effect on financial performance.

Sukmadinata (2009) explains that Research and Development is a strategy or method that can be used to improve the company's practice. Furthermore, Kinkel et al. (2005) explained that research and development improvement will produce innovative and high-tech products, and enable companies to gain competitive advantage and gain market share, so that companies must invest more resources in Research and development activities. The results of research and development are not only the development of an existing product; but also, to find knowledge or problems with practical answers. Research and development provide opportunities for companies to develop better products and production processes and also more effective sales innovations to increase company value (Padgett and Galan, 2010). Previous empirical studies have shown a positive effect of RnD on firm performance. Ghaffar (2014) has proven that research and development have a positive effect on company performance. The results of other studies also showed that the previous year's RnD investment will mature in the following year in the form of innovative products/processes, which increase company profitability and cash flow (Usman et al, 2017). Based on the explanations that have been described, the hypothesis that can be proposed is:

\section{$\boldsymbol{H}_{2}$ : Research and development have a positive effect on financial performance.}

Padgett and Galan (2010) explained that through research and development (RnD) activities, firms can develop their products and have better production processes and effective sales innovations. Companies that allocate higher Research and Development expenditures are expected to get more benefits than those that do not (Wang, 2011). This study attempts to examine the moderating role of $\mathrm{RnD}$ to strengthen the relationship between IC and firm financial performance. RnD will affect intellectual capital resources in the process of corporate development and corporate value creation. It is because IC needs some innovation capabilities in order to generate maximum value for the company. Karchegani, et al. (2013) explained that intellectual capital (IC) is the main asset that helps companies to create value and enables the companies to be innovative by boosting the organizational performance through knowledge, experiences, skills of employees and also by defining new methods of task performance and being 
innovative in their processes. On the other hand, to be able to affect the company's innovation, IC needs to be systematically supported by innovation capabilities, one of which could be expressed by companies RnD intensity. Therefore, this study expects that the existence of research and development will lead to more optimal impact from intellectual capital in improving the firm financial performance. Based on the explanations that have been described, the hypothesis that can be proposed is:

$\boldsymbol{H}_{3}$ : Research and Development intensity strengthen the positive effect of intellectual capital towards firm financial performance.

\section{Research Method}

\section{Data and Sample}

The type of data used in this study is secondary data. This study uses data generated from the financial statements of non-financial companies listed in Indonesia, Malaysia, Singapore, and Philippine Stock Exchanges. Financial report data is obtained directly from each companies' official website. The initial sample consists of 123 non-financial companies with years of observations during 2015-2017 that having research and development activity. Due to incomplete data on the variables selected, the final sample observation used in this study amounts to 327 firm-year observations instead of 369 .

\section{Variables}

a. Intellectual Capital (VAIC). IC measured using VAIC which was developed by Pulic $(2000,2004)$. VAIC measured by the following equation:

$$
\mathrm{VAC}_{\mathrm{t}}=\mathrm{HCE}_{\mathrm{t}}+\mathrm{SCE}_{\mathrm{t}}+\mathrm{CEE}_{\mathrm{t}}
$$

Where:

$\begin{array}{ll}\text { VAICt } & =\text { Value added intellectual coefficient at } \mathrm{t} \\ \mathrm{HCEt} & =\mathrm{VAt} / \mathrm{HCt} \text {; human capital efficiency coefficient at } \mathrm{t} \\ \mathrm{SCEt} & =\mathrm{SCt} / \mathrm{VAt} \text {; structural capital efficiency coefficient at } \mathrm{t} \\ \mathrm{CEEt} & =\mathrm{VAt} / \mathrm{CEt} \text {; capital employed efficiency coefficient at } \mathrm{t} \\ \mathrm{Vat} & =\text { OUTt }- \text { INt }=\mathrm{OPt}+\mathrm{ECt}+\mathrm{Dt}+\mathrm{At} \text {; VA is the calculation of output (OUTt) } \\ & \text { calculated from total sales reduced by Input (INt) calculated from bought-in } \\ & \text { materials or cost of goods or services sold; or it could be the calculation of } \\ & \text { operating income (OPt); employee costs (ECt); depreciation (Dt); and } \\ & \text { amortization (At) } \\ \mathrm{HCt} & =\text { total salaries and wages at t } \\ \mathrm{SCt} & =\text { VAt }-\mathrm{HCt} \text {; structural capital at } \mathrm{t} \\ \mathrm{CEt} & =\text { book value of the net assets at } \mathrm{t}\end{array}$


- Human Capital Efficiency (HCE). HCE is a component of VAIC which represents the efficiency of human capital or the ability to apply the skills and expertise efficiently (Pulic, 2000, 2004).

- Structural Capital Efficiency (SCE). SCE is a component of VAIC which represents the efficiency of structural capital and relational capital (Pulic, 2000, 2004).

- Capital Employed Efficiency (CEE). CEE is a component of VAIC that represents an efficient use of physical and financial capital (Pulic, 2000, 2004).

b. Research and Development. RnD is used as an Independent and Moderating Variable. $\mathrm{RnD}$ is proxied by the $\mathrm{RnD}$ intensity measured using a formula refers to the research of Krishnan, Tadepalli, and Park (2009), as follows:

$$
\text { RnD Intensity = Research and Development } / \text { Total Revenue }
$$

c. Firm Financial Performance (Firm_Perf). Financial performance is used as a dependent variable. Follows the study from Pratama (2016), Pratama and Wibowo (2017) and Pratama (2018), the firm financial performance is measured by ROA (return on assets ratio). ROA is calculated by the following equation:

$$
\text { ROA = Profit before tax / Average total assets } .
$$

d. Firm Size (FSize). Firm size is used as a control variable. Firm size is measured by using the firm's total assets at year $t$, then calculated the natural logarithm.

e. Leverage (Lev). Leverage is used as a control variable. Leverage is calculated by dividing long-term liabilities to total assets.

\section{Regression Model}

According to Gujarati and Porter (2009), the research which uses panel data should be tested by panel data regression model analysis, i.e. fixed effect regression or random effect regression. This study was used panel data regression model analysis by doing a Hausman test first to decide whether to use the fixed effect regression or random effect regression.

The analysis done in this study is aggregated analysis which aggregates the data analysis of Indonesia, Malaysia, Singapore, and the Philippine into one sample and analyzes them together. The hypotheses testing in this study were using two-equation models. Model (1) was used to examine the effect of IC and RnD towards firm financial performance (Hypothesis 1 and Hypothesis 2). Meanwhile, model (2) is used to examine the moderating role of $\mathrm{RnD}$ on the effect of IC towards firm financial performance (Hypothesis 3 ). The equation models used to test all of the hypotheses in this study are as follows: 
Model 1 Model to test the effect of IC and RnD towards Firm Financial Performance

$$
R O A=\beta_{0}+\beta_{1} \text { VAIC }+\beta_{2} R_{n D}+\beta_{3} \text { Fize }_{t}+\beta_{4} \operatorname{Lev}_{t}+\varepsilon_{t}
$$

Model 2 Model to test the moderating effect of RnD on the effect of IC towards Firm Financial Performance

$$
\text { ROA }=\beta_{0}+\beta_{1} \text { VAIC }+\beta_{2} \text { RnD }+\beta_{3} \text { VAIC } * \text { RnD }+\beta_{4} \text { FSize }_{t}+\beta_{5} \text { Lev }_{t}+\varepsilon_{t}
$$

\begin{tabular}{|c|c|}
\hline ROA & = Financial performance \\
\hline VAIC & $=$ Intellectual Capital \\
\hline $\mathrm{RnD}$ & $=$ Research and Development \\
\hline VAIC*Fam OWN & $=$ Interaction Variable between $\mathrm{RnD}$ and IC \\
\hline FSize & = Firm Size \\
\hline Lev & $=$ Leverage \\
\hline$\varepsilon \mathrm{t}$ & $=$ error term \\
\hline
\end{tabular}

Where:

\section{Result and Discussion}

\section{Descriptive Statistics}

Table 1 showed the descriptive statistics of the selected variables in this study. ROA has a mean value of 10.07664 which indicates that the firms have fairly good profitability. Meanwhile, VAIC which is the proxy of the firm's intellectual capital has a mean value of 3.830977. The RnD intensity has a mean value of 0.012463 . Overall, the descriptive statistics of each variable can be seen in Table 1.

Table 1 Descriptive Statistics of Selected Variables

\begin{tabular}{lrrrr}
\hline Variable & Minimum & \multicolumn{1}{c}{ Maximum } & Mean & \multicolumn{1}{c}{ Std. Dev. } \\
\hline ROA & 0.070 & 51.69 & 10.07664 & 9.259581 \\
VAIC & 0.9782588 & 9.643191 & 3.830977 & 1.741388 \\
RnD & 0.0001001 & 0.0868945 & 0.012463 & 0.0195002 \\
FSize & 17.08975 & 26.89956 & 21.99371 & 2.081531 \\
Lev & 0.4643257 & 0 & 0.0855298 & 0.1181211 \\
\hline
\end{tabular}

Hypotheses 1 of the study aims to answer the question of whether there is a positive effect of intellectual capital on firm financial performance. Table 2 showed the results of the hypothesis 1 test in this study. The result showed that VAIC has a significant positive effect on ROA as the proxy of firm financial performance with a coefficient amounted to 1.852284 at a significance level of $\alpha=1 \%$. This indicates that if a firm can use its IC more efficiently, it can lead to the improved financial performance of the firm. Therefore, hypothesis 1 which states that intellectual capital has a positive effect on the firm financial performance is supported. 
The result indicates that the efficient and effective use of IC will lead the firm to achieve higher financial performance. This means that in the era of AEC, companies should be more aware of the efficient and effective use of intellectual capital so that they can face AEC challenges. The result of this study is consistent with previous studies conducted by Chen et al. (2005), Clarke et al. (2011), Pratama (2016), Pratama and Wibowo (2017), and Pratama (2018) which found that intellectual capital is positively affected ROA which is the proxy of firm financial performance. This is in accordance with the resourcebased theory which explained that intellectual capital (IC) is a resource that is the core of value creation and competitive advantage for the firm (Barney, 1991). According to Chen et al. (2005) and Wang (2008), sustainable competitive advantages from IC will enable a firm to beat the competition and also create added value so that it can contribute to the firm's success.

Table 2 Hypothesis 1, 2 and 3 results

\begin{tabular}{|c|c|c|c|c|}
\hline \multirow{4}{*}{ Independent Variables } & \multicolumn{2}{|c|}{ Model 1} & \multicolumn{2}{|c|}{ Model 2} \\
\hline & \multicolumn{4}{|c|}{ Dependent Variable } \\
\hline & \multicolumn{2}{|l|}{ ROA } & \multicolumn{2}{|c|}{ ROA } \\
\hline & Coeff. & $t$ & Coeff & $\mathbf{t}$ \\
\hline Const & 9.235249 & 0.38 & -13.54926 & -1.85 \\
\hline VAIC & 1.852284 & $5.02 * *$ & 0.4533223 & 0.99 \\
\hline $\mathrm{RnD}$ & 404.1925 & $5.80 * *$ & 290.5072 & $21.77 * *$ \\
\hline VAIC*RnD & & & 6.988843 & $7.27^{*}$ \\
\hline FSize & -0.5030026 & -0.46 & 0.5770039 & 1.83 \\
\hline Lev & -2.680185 & -0.48 & -3.133025 & -0.71 \\
\hline $\mathrm{R}^{2}$ Within & & 0.6013 & & 0.6679 \\
\hline $\mathrm{F}$ & & 39.41 & & 966.08 \\
\hline Prob $>\mathrm{F}$ & & 0.0000 & & 0.0010 \\
\hline
\end{tabular}

Hypotheses 2 of the study aims to answer the question of whether there is a positive effect of research and development on firm financial performance. Table 2 showed the results of the hypothesis 2 test in this study. The result showed that RnD Intensity has a significant positive effect on ROA as the proxy of firm financial performance with a coefficient amounted to 404.1925 at a significance level of $\alpha=1 \%$. This indicates that the firm's research and development intensity can lead to the improved financial performance of the firm. Therefore, hypothesis 2 which stated that research and development have positive effect on the firm financial performance is supported.

The result indicates that Research and Development are proved to be able to help companies to succeed in this competitive environment. Align with the explanation from Pedgett and Galan (2010), who stated that through research and development (RnD) activities, firms can develop their products and have better production processes and effective sales innovations. Companies that allocate higher Research and Development expenditures are getting more benefits than those that do not (Wang, 2011). The result of this study is consistent with previous studies conducted by Usman, et al. (2017) and Ghaffar (2014) who have examined the effect of RnD towards firm financial 
performance, the results of their studies stated that $\mathrm{RnD}$ had a positive effect towards the firm financial performance.

Hypotheses 3 of the study aims to answer the question of whether there is a moderating role of $\mathrm{RnD}$ on the relationship between IC and firm financial performance. Table 2 showed the results of hypothesis 3 test in this study. The result showed that VAIC*RnD has a significant positive effect on ROA with a coefficient amounted to 6.988843 at a significance level of $\alpha=5 \%$. This indicates that the firm's research and development intensity can strengthen the relationship between IC and ROA as the proxy of firm financial performance. Therefore, hypothesis 3 which states that Research and Development intensity strengthen the positive effect of intellectual capital towards firm financial performance is supported.

The results proved that the existence of research and development will lead to a more optimal impact from intellectual capital in improving the firm financial performance. $\mathrm{RnD}$ will affect intellectual capital resources in the process of corporate development and corporate value creation. It is because IC needs some innovation capabilities in order to generate maximum value for the company. Karchegani, et al. (2013) explained that intellectual capital (IC) is a vital asset that helps companies to create value and enables the companies to be innovative by boosting the organizational performance through knowledge, experiences, skills of employees and also by defining new methods of task performance and being innovative in their processes. On the other hand, to be able to affect the company's innovation, IC needs to be systematically supported by innovation capabilities, one of which could be expressed by companies RnD intensity.

\section{Conclusion}

This study examined the positive impact of IC on the performance of the firms operating in the non-financial industry in ASEAN countries, namely Indonesia, Malaysia, the Philippines, and Singapore. The empirical results showed that intellectual capital has a positive effect on firm financial performance. This indicates that the efficient and effective use of intellectual capital will make the firm achieve higher financial performance. This implies that in the era of AEC, companies should be more aware of the efficient and effective use of intellectual capital so that they can face AEC challenges.

This study also examined the positive impact of Research and Development on firm financial performance. The empirical results found RnD has a positive effect on firm financial performance. Research and Development are proved to be able to help companies to succeed in this competitive environment. Companies that allocate higher Research and Development expenditures are getting more benefits than those that do not.

Hypothesis 3 of the study aims to answer the question of whether research and development conducted by the firm could strengthen the effect of IC towards firm 
financial performance. The results supported the hypothesis and proved that the existence of research and development will lead to a more optimal impact from intellectual capital in improving the firm financial performance.

This study has several limitations. First, this study only uses samples of the firms that operate in a non-financial industry in ASEAN countries, so the results of this study may not be generalizable to the firms with different types of industries, for the example banking industry. Further research can use several firms from various industries and compared them in order to determine the complete picture of relationship between intellectual capital and research and development on firm financial performance from the standpoint of a more comprehensive range of industries.

Finally, this study uses VAIC which is a measurement of intellectual capital from accounting information of the firm. Further research can use another proxy for measuring the firm's intellectual capital by combining measurements of intellectual capital using monetary and non-monetary methods.

\section{References}

Andriana, D. (2014). Pengaruh Intellectual Capital Terhadap Kinerja Keuangan Perusahaan. Jumal Riset Akuntansi and Keuangan, 2(1), 251-260. https://doi.org/10.17509/jrak.v2i1.6578

Barney, J. B. (1991). Firm resources and sustained competitive advantage. Journal of Management, 17(1), 99-120. https://doi.org/10.1177/014920639101700108

Barney, J. B., Ketchen, D. J., \& Wright, M. (2011). The future of resource based theory: Revitalization or decline? Journal of Management, 37(5), 1299-1315.

https://doi.org/10.1177/0149206310391805

Bontis, N. (1996). There's a price on your head: managing intellectual capital strategically. Business Quarterly, 60(4), 40-47.

Chan, K. H. (2009). Impact of intellectual capital on organisational performance: An empirical study of companies in the Hang Seng Index (Part 1). The Learning Organization, 16(1), 4-21. https://doi.org/10.1108/09696470910927641

Chan, K. H. (2009). Impact of intellectual capital on organizational performance: An empirical study of companies in the Hang Seng Index (Part 2). The Learning Organization, 16(1), 22-39. https://doi.org/10.1108/09696470910927650

Chen, M. C., Cheng, S. J., \& Hwang, Y. (2005). An empirical investigation of the relationship between intellectual capital and firms' market value and financial performance. Journal of Intellectual Capital, 6(2), 159-176. https://doi.org/10.1108/14691930510592771

Clarke, M., Seng, D., \& Whiting, R. H. (2011). Intellectual capital and firm performance in Australia. Journal of Intellectual Capital, 12(4), 505-530. https://doi.org/10.1108/14691931111181706

Firer, S. \& Williams, S. M. (2003). Intellectual capital and traditional measures of corporate performance. Journal of Intellectual Capital, 4(3), 348-360. https://doi.org/10.1108/14691930310487806 
Ghaffar, A., \& Khan, W. A. (2014). Impact of Research and Development on Firm Performance. International Journal of Accounting and Financial Reporting, 4(1), 357-367. https://doi.org/10.5296/ijafr.v4i1.6087

Gleason, K. I. \& Klock, M. (2006). Intangible capital in the pharmaceutical and chemical industry. The Quarterly Review of Economics and Finance, 46(2), 300-314. https://doi.org/10.1016/j.qref.2005.03.001

Gujarati, D. N. \& Porter, D. C. (2009). Basic Econometrics $5^{\text {th }}$ edition. McGraw Hill/Irwin. New York, USA.

Karchegani, M. R., Sofian, S., \& Amin, S. M. (2013). The Relationship Between Intellectual Capital and Innovation: A Review. International Journal of Business and Management Studies, 2(1), 561-581.

Kinkel, S., Lay, G., \& Wengerl, J. (2005). Innovation: More than Research and Development. Bulletins of the Manufacturing Performance Survey, 33, 1-12.

Kozlenkova, I. V., Samaha, S. A., \& Palmatier, R. W. (2014). Resource-based theory in marketing. Journal of the Academy of Marketing Science, 42(1), 1-21. https://doi.org/10.1007/s11747-013-0336-7

Krishnan, H. A., Tadepalli, R., \& Park, D. (2009). R\&D Intensity, Marketing Intensity, and Organizational Performance. Journal of Managerial Issues, 21(2), 232-244.

Maditinos, D., Chatzoudes, D., Tsairidis, C., \& Theriou, G. (2011). The impact of intellectual capital on firms' market value and financial performance. Journal of Intellectual Capital, 12(1), 132-151. https://doi.org/10.1108/14691931111097944

Nahapiet, J. \& Ghoshal, S. (1998). Social capital, intellectual capital, and the organizational advantage. Academy of Management Review, 23(2), 242-266. https://doi.org/10.5465/amr.1998.533225

Oswald, D. R. \& Zarowin, P. (2007). Capitalization of R\&D and the Informativeness of Stock Prices. European Accounting Review, 16(4), 703-726. https://doi.org/10.1080/09638180701706815

Padgett, R. C. \& Galan, J. I. (2010). The Effect of R\&D Intensity on Corporate Social Responsibility. Journal of Business Ethics, 93(3), 407-418. https://doi.org/10.1007/s10551-009-0230-x

Peteraf, M. \& Barney, J. B. (2003). Unraveling the resource-based tangle. Managerial and Decision Economics, 24(4), 309-323. https://doi.org/10.1002/mde.1126

Pratama, B. C. (2016). The Impact of Intellectual Capital of Indonesian's High-Tech Company on Firm's Financial and Market Performance. International Journal of Academic Research in Accounting, Finance and Management Sciences, 6(4), 73-81.

Pratama, B. C. (2018). Family Ownership Role in Strengthening the Relationship Between Intellectual Capital and Financial Performance: Research in High-Tech Firms in Indonesia and Philippines. Advances in Social Science, Education and Humanities Research. 231, 326-329. https://doi.org/10.2991/amca-18.2018.89

Pratama, B. C. \& H. Wibowo. (2017). Family Ownership and the Entrenchment Effect on Intellectual Capital Utilization: A Study of High-Technology Companies in Indonesia Dealing with the ASEAN Economic Community (AEC). Jurnal Akuntansi dan Investasi, 18(2), 222-230. https://doi.org/10.18196/jai.1802585

Pulic, A. (2000). VAIC: an accounting tool for IC management. International Journal of Technology Management, 20(5-8), 702-714. https://doi.org/10.1504/ijtm.2000.002891

Pulic, A. (2004). Intellectual capital - does it create or destroy value?. Measuring Business Excellence, 8(1), 62-68. https://doi.org/10.1108/13683040410524757

Sukmadinata, N. S. (2009). Metode Penelitian Pendidikan. Remaja Rosdakarya. Bandung, Indonesia. 
Sullivan Jr., P. H. \& Sullivan Sr., P. H (2000). Valuing Intangible Companies, an Intellectual Capital Approach. Journal of Intellectual Capital, 1(4), 328-340. https://doi.org/10.1108/14691930010359234

Usman, M., Shaique, M., Khan, S., Shaikh, R., \& Baig, N. (2017). Impact of R\&D Investment on Firm Performance and Firm Value: Evidence From Developed Nations (G-7). Revista de Gestão, Finanças e Contabilidade, 7(2), 302-321.

Wang, C. H. (2011). The moderating role of power asymmetry on the relationships between alliance and innovative performance in the high-tech industry. Technological Forecasting \& Social Change, 78(7), 1268-1279. https://doi.org/10.1016/j.techfore.2011.03.017

Wang, J. C. (2008). Investigating market value and intellectual capital for S\&P 500. Journal of Intellectual Capital, 9(4), 546-563. https://doi.org/10.1108/14691930810913159 